\title{
New Records of Endocoelantheainea and Nynantheae (Anthozoa: Zoantharia: Actiniaria) from Korea
}

\author{
Sung-Jin Hwang and Jun-Im Song* \\ Division of EcoScience, Ewha Womans University, Seoul 120-750, Korea
}

\begin{abstract}
Actiniarians were collected from the rocks and sand bed of Jejudo Island, Ulleungdo Island, and Wangdolcho in Korean waters from 2004 to 2009. They were classified as two species of two families belonging to the suborders Endocoelantheainea and Nynantheae. Especially, suborder Endocoelantheainea, with distinct development of mesenteries, was firstly added to Korean athenarian fauna with the species, Halcurias carlgreni McMurrich, 1901. Calliactis polypus (Forskål, 1775) showing the commensalism with hermit crab, was easily distinguished from $C$. japonica by external features and the composition of cnidae. These two species were described in detail with tables and figures.
\end{abstract}

Keywords: taxonomy, Anthozoa, Actiniaria, Halcuriidae, Homathiidae

\section{INTRODUCTION}

The order Actiniaria was recently redivided into four suborders, Endocoelantheainea, Nynantheae, Protantheae, Ptychodateae (Fautin, 2005). Only 27 species of Nynantheae with three infraorders have been reported in the Korean waters so far (Song, 2004). Among the species, 23 and 4 species are belonging to infraorder Thenaria and Athenaira, respectively. The infraorder Thenaria which is characterized by a well developed flat pedal disc are divided into three superfamilies, Acontiaria, Endomyaria, and Mesomyaria. Actiniaria belonging to suborder Endocoelantheainea has the distinct arrangement of mesenteries from a regular form (Manuel, 1988), which develop in endocoels, while mesenteries of species in the other three suborders develop in exocoels.

In this paper, each species in the suborder Endocoelantheainea and in the superfamily Acontiaria of suborder Nynantheae is newly added. Consequently, Korean actiniarians become one species in the suborder Endocoelantheainea and 28 species in the suborder Nynantheae (Song, 1984, 1992, 2003, 2004; Song and Lee, 1998; Song and Cha, 2001, 2002, 2004).

\section{MATERIALS AND METHODS}

All specimens were collected from the subtidal zones in the southern coast of Jejudo Island, Ulleungdo Island, and

\footnotetext{
*To whom correspondence should be addressed

Tel: 82-2-3277-2364, Fax: 82-2-3277-2385

E-mail: jisong@ewha.ac.kr
}

Wangdolcho of East Sea by SCUBA from 2004 to 2009. The living actiniarians were photographed using a 5060-WZ digital camera (Olympus) equipped an Underwater Patima 7070 Housing. The collected specimens were photographed by $\mathrm{G} 7$ digital camera (Canon) prior to being anesthetized with menthol for 4-6 hours, and then fixed in 4-5\% (v/v) neutral formalin with seawater.

For the identification, each specimen was examined for external features such as the size of each part of individuals, number of tentacles, and coloration under a Semi SV-6 stereomicroscope (Zeiss).

Preserved specimens were examined based on the morphological characters ascertained microscopically and histologically. The cnidae were examined by squashing a bit of tissue in a drop of phenol-glycerol solution and measuring with an ocular micrometer at a magnification of 1,000 using light microscopes (Olympus BH-2 and Zeiss Axioscope 2).

Anatomical studies were conducted by routine histological procedure with paraffin embedded tissue slices. They were observed under a Semi SV-11 stereomicroscope (Zeiss) and images were acquired by a 5060-WZ digital camera (Olympus) attached to the stereomicroscope.

\section{SYSTEMATIC ACCOUNTS}

Phylum Cnidaria Hatschek, 1888

Class Anthozoa Ehrenberg, 1834

Subclass Zoantharia de Blainville, 1830

Order Actiniaria Hertwig, 1882

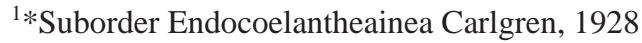


Actiniaria with peculiar development of mesenteries different from normal type. After first 6 pairs of mesenteries developed, following pairs arranged in lateral endocoeles. Mesenteries divisible into macro- and microcnemes or not. Well developed pedal disc but without basilar muscles. Margin tentaculate and column without verrucae. Tentacles variable in number. No sphincter. Longitudinal muscles of tentacles and radial muscles of oral disc meso-ectodermal. Siphonoglyph one or two.

\section{${ }^{1}$ Family Halcuriidae Carlgren, 1918}

Body elongated not lobed. Column with or without nematocyst batteries. Tentacles rather few, up to 70 in more than two cycles, and without basal swellings on their aboral side. One siphonogryph. Mesenteries divisible into macro- and microcnemes, 6 or 10 pairs of macrocnemes. Some of microcnemes perfect. Retractors of macrocnemes well developed and restricted. Macrocnemes fertile with filaments, but microcnemes sterile without filaments.

\section{${ }^{2 *}$ Genus Halcurias McMurrich, 1893}

Body almost smooth, but often with nematocyst batteries. Distal margin of column not lobed. Margin tentaculate or with parapet. No sphincter. Tentacles up to 70 arranged in cycles. Typical arrangement of mesenterial pairs in 4 cycles, $10(6+4)+8+16$. Macrocnemes 10 pairs, fertile, filamented and with strongly restricted, reniform retractors. Microcnemes only in upper part of body, some of them perfect. Parietobasilar muscles rather well developed to fairly weak. Dioecious.

\section{${ }^{3}$ Halcurias carlgreni McMurrich, 1901 (Figs. 1, 2, 5A-D, Tables 1, 2)}

Halcurias carlgreni McMurrich, 1901, p. 159; Carlgren, 1940, p. 22; 1949, p. 19; Uchida, 2004, p. 9, pl. 1, figs. A, B; Uchida and Soyama, 2001, p. 17.

Materials examined. 1 ind., Jejudo Island, Munseom (33 $\left.13^{\prime} 40.82^{\prime \prime} \mathrm{N}, 126^{\circ} 34^{\prime} 05.55^{\prime \prime} \mathrm{E}\right), 10$ Apr. 2004 (S.J. Hwang), $35 \mathrm{~m}$ deep; 1 ind., Jejudo Island, Munseom (33 $13^{\prime} 40.06^{\prime \prime} \mathrm{N}$, $\left.126^{\circ} 33^{\prime} 49.62^{\prime \prime} \mathrm{E}\right), 9$ May. 2004 (S.J. Hwang), $32 \mathrm{~m}$ deep; 1 ind., Ulleungdo Island, 22 Jun. 2005 (S.J. Hwang), $32 \mathrm{~m}$ deep; 1 ind. $\sigma^{7}$, Wangdolcho $\left(36^{\circ} 43^{\prime} 874^{\prime \prime} \mathrm{N}, 129^{\circ} 44^{\prime} 169^{\prime \prime}\right.$ E), 7 Jun. 2006 (J.I. Song, S.J. Hwang, E.J. Choi and H.W. Moon), $15-30 \mathrm{~m}$ deep; 3 inds., Wangdolcho $\left(36^{\circ} 41^{\prime} 345^{\prime \prime} \mathrm{N}\right.$, $\left.129^{\circ} 45^{\prime} 075^{\prime \prime} \mathrm{E}\right), 8$ Jun. 2006 (J.I. Song, S.J. Hwang, E.J.
Choi and H.W. Moon), $15 \mathrm{~m}$ deep; 3 inds., Jejudo Island, Munseom (33 $\left.13^{\prime} 40.06^{\prime \prime} \mathrm{N}, 126^{\circ} 33^{\prime} 49.62^{\prime \prime} \mathrm{E}\right), 3$ Feb. 2009 (S.J. Hwang and E.J. Choi), 34-41 m deep.

Description. Body elongate and cylindrical. Column almost smooth, with longitudinal and horizontal striate, color points, not lobed in distal part. In preserved specimens small nematocyst batteries on distal part of column scarcely visible under stereomicroscope. Margin with parapet, consequently with fosse. Number of tentacles up to 68 in adult and 31-35 in young. Body size in Table 1. Inner tentacles longer than outer. Length of inner 3-9 $\mathrm{mm}$ and outer 2-7 $\mathrm{mm}$ in extended young, and $4-13 \mathrm{~mm}$ and $3-11.5 \mathrm{~mm}$ in extended adult respectively. In contracted state, height of body $5 \mathrm{~mm}$ and 12$15 \mathrm{~mm}$, diameter of column $4 \mathrm{~mm}$ and $8-11 \mathrm{~mm}$, diameter of oral disc $1.2 \mathrm{~mm}$ and 3-4 mm, diameter of pedal disc $3 \mathrm{~mm}$ and $4-6 \mathrm{~mm}$ in young and adult, respectively. In extended state, height of body $9-10.5 \mathrm{~mm}$ and $24.5-38 \mathrm{~mm}$, diameter of column $4.5-7 \mathrm{~mm}$ and $8-16 \mathrm{~mm}$, diameter of oral disc 1 $2.5 \mathrm{~mm}$ and $3.5-5 \mathrm{~mm}$, diameter of pedal disc 5-6 $\mathrm{mm}$ and $10-20 \mathrm{~mm}$ in young and adult, respectively.

Actinopharynx with one siphonoglyph, 16-17 distinctly well developed longitudinal ridges. Mesogloea of column comparing thicker than endoderm and ectoderm. Distal margin of column tentaculate. Longitudinal muscles not found in ectoderm of column. Tentacular muscles meso-ectodermal. Mesenteries arranged in 4 cycles $(6+4+8+16)$, of which first 10 pairs perfect macrocnemes and later 24 pairs imperfect microcnemes. Macrocnemes with filaments and well developed restricted retractors extended along whole body, but microcnemes without filaments and retractors developed at only upper part of body. Gonads only developed in macrocnemes under lower actinopharynx. Retractor muscles restricted, and less reniform at upper part of actinopharynx, but clearly reniform from lower part of actinopharynx. Parietobasilar muscles developed at middle part of column, but basilar muscles absent. Dioecious. Spemaries observed in macrocnemes of specimens collected on June 2006. For asexual reproduction, pedal disc of specimens only sampled on June 2005 and 2006 appeared distinct swellings presumed pedal laceration.

Cnidom: spirocysts, basitrichs, microbasic p-mastigophores.

Distribution and size of cnidae are measured as follow (Table 2).

In color of living adult, column vivid orange with little dark orange spots in middle parts. Upper side of column pale orange and downward to pedal disc yellowish orange. Pedal disc and oral cone brilliant lemon yellow. Oral disc and tentacles with longitudinal orange stripes on both sides almost colorless. In living young, column almost pale orange with

\footnotetext{
$1 *$ 별란말미잘과 (신칭), ${ }^{2}$ *별란말미잘속 (신칭), ${ }^{3 *}$ 별란말미잘 (신칭)
} 


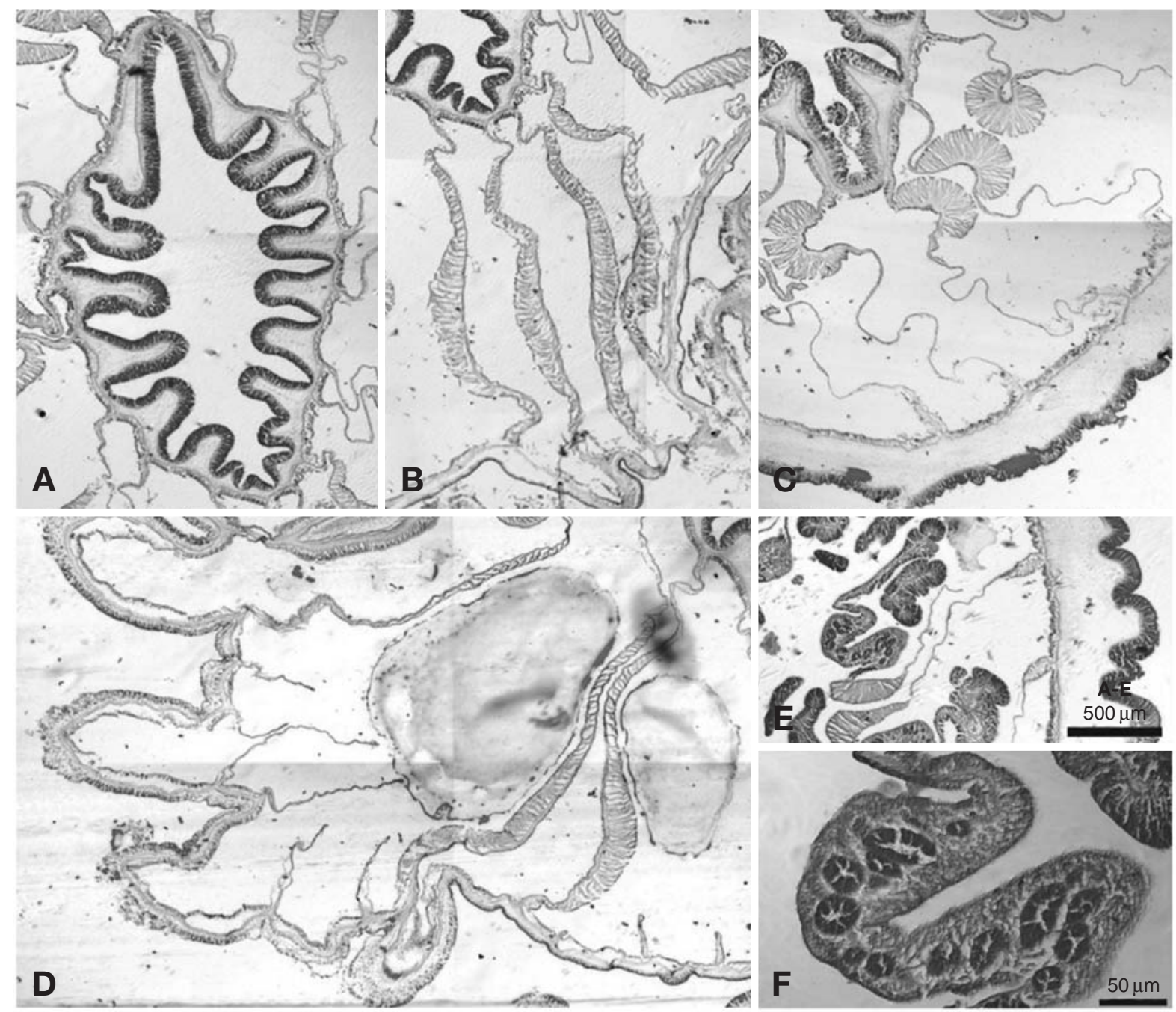

Fig. 1. Mesenteries of Halcurias carlgreni. A, siphonoglyph and pharyngeal ridges at lower actinopharynx; $B$, directive at upper actinopharynx; C, directive at lower actinopharynx; D, perfect, imperfect 2nd and 3rd mesenteries; E, mesenterial filaments with spermeries; $F$, developing spermeries.

little dark tone spots. Oral disc colorless or yellow. Pedal disc and tentacles colorless. Preserved specimens colorless. Habitat. This species inhabits at horizontal rocky substrate between 15 and $41 \mathrm{~m}$ deep.

Remarks. It is a little different from H. carlgreni by Uchida (2004) in that the mesenteries of the third cycle are not perfect and lacking retractor muscles in our specimens. For spirocysts in Actiniaria, there is usually slender type, but stout type is numerously observed together with slender spirocysts in this species from our specimens (spirocysts II) and Uchida, 2004. In addition, other species of Halcurias also have stout spirocysts. The shape of stout spirocyst is fairly different with that of slender one. The diameter of both ends are somewhat thinner when they are compared with plump middle part, but almost same in diameter. How- ever, thin capsules and coiling pattern of stout spirocyst are similar with those of slender one. H. carlgreni shows a variety of depth distribution from $15 \mathrm{~m}$ depth in Korean waters to greater depths in water of China Sea (55-137 m) and Japanese waters (30-250 m) (Carlgren, 1949; Uchida, 2004). Distribution. Korea (Jejudo Island, East Sea, Korea Strait), Japan (Hirado Strait, Goto Island, Noto-Kawajiri, Shinomisaki, Satono, Tanami, Izu-Oshima, Uozu Harbor), China Sea.

\section{Suborder Nynantheae Carlgren, 1899}

Actiniaria with a rounded or flat base with or without basilar muscles. Column smooth or with outgrowths of one sort or another, rarely (and then especially in uppermost part) provided with ectodermal muscles. Sphincter absent or 


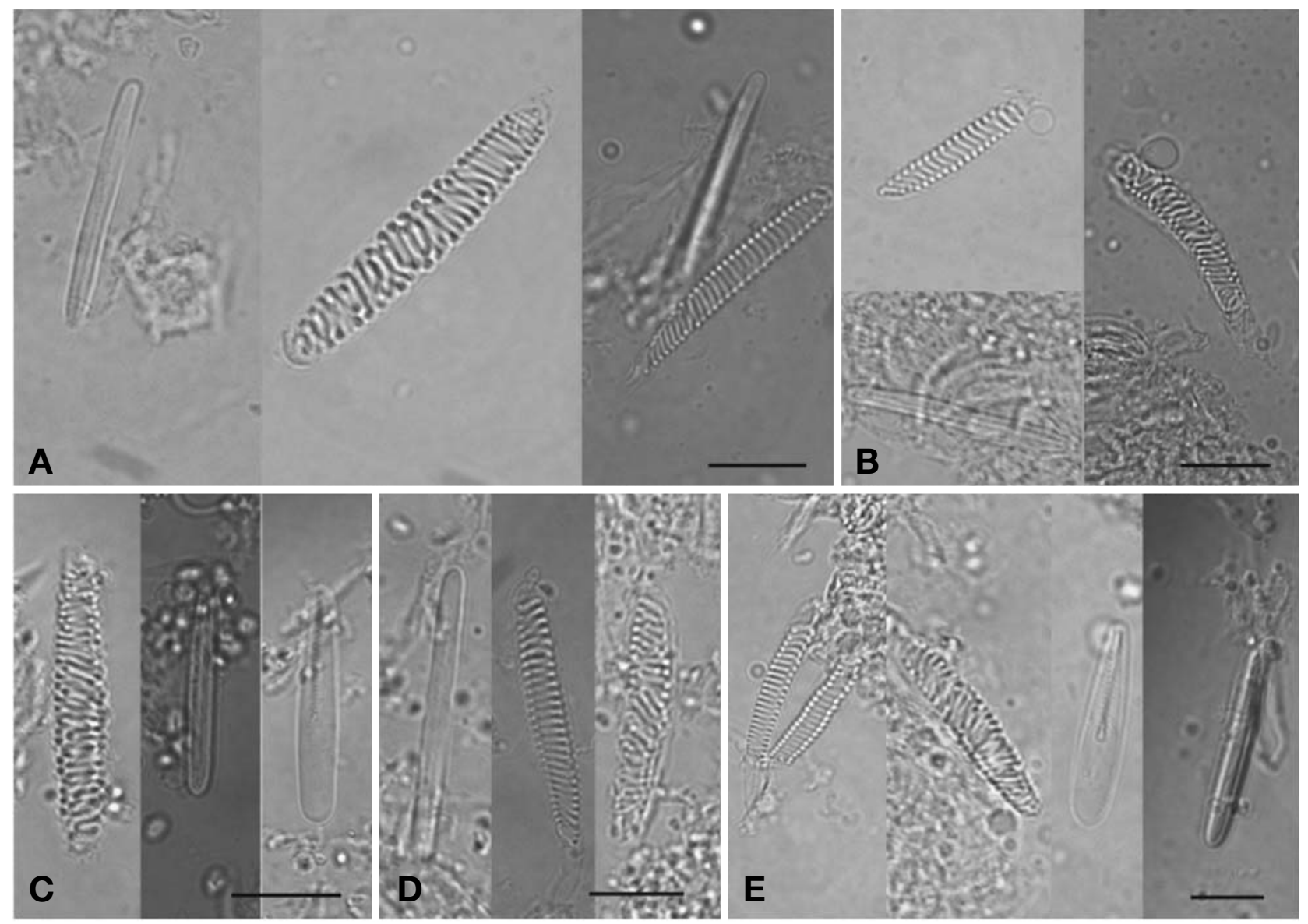

Fig. 2. Cnidae of Halcurias carlgreni. A, tip of tentacle; B, base of tentacle; $C$, actinopharynx; $D$, column; $E$, filament. Scale bars= $10 \mu \mathrm{m}$.

Table 1. External size $(\mathrm{mm})$ in relation to age and state of Halcurias carlgreni specimens ( $L$ length, $D$ diameter)

\begin{tabular}{|c|c|c|c|c|c|c|c|c|}
\hline \multirow{4}{*}{ Parts } & \multicolumn{8}{|c|}{ State } \\
\hline & \multicolumn{4}{|c|}{ Contracted } & \multicolumn{4}{|c|}{ Extended } \\
\hline & \multicolumn{2}{|c|}{ Young } & \multicolumn{2}{|c|}{ Adult } & \multicolumn{2}{|c|}{ Young } & \multicolumn{2}{|c|}{ Adult } \\
\hline & $L$ & $D$ & $L$ & $D$ & $L$ & $D$ & $L$ & $D$ \\
\hline Tentacle-inner & $3.8-6$ & & $4-11.5$ & & $3-9$ & & $4-13$ & \\
\hline -outer & $2-5$ & & $3-10$ & & $2-7$ & & $3-11.5$ & \\
\hline Total height & 5 & & $12-15$ & & $9-10.5$ & & $24.5-38$ & \\
\hline Column & & 4 & & $8-11$ & & $4.5-7$ & & $8-16$ \\
\hline Oral disc & & 1.2 & & $3-4$ & & $1-2.5$ & & $3.5-5$ \\
\hline Pedal disc & & 3 & & $4-6$ & & $5-6$ & & $10-20$ \\
\hline
\end{tabular}

present, endodermal or mesogloeal. Tentacles simple or complex, commonly arranged in cycles, sometimes in radial rows. Siphonoglyphs usually attached to directives, rarely to nondirectives, when directives absent. Mesentereis arragned in cycles, commonly hexamerously. Secondary mesenteries develop in exocoels. Retractors of paired non-directives face one another. Mesenterial filaments with ciliated tracts. Holo- trichous nematocysts only exceptionally present, and never in endoderm.

Infraorder Thenaria Carlgren, 1899

Nynantheae with basilar muscles. Aboral end flattened and adherent, distinctly differentiated from column. Bodywall 
Table 2. Size range and mean value of cnidae according to parts of Halcurias carlgreni ( $n$ number of cnidae measured)

\begin{tabular}{|c|c|c|c|}
\hline Parts & Cnidae & Length $\times$ Width $($ mean $\pm S D, \mu m)$ & $n$ \\
\hline Tentacle-tip & $\begin{array}{l}\text { Spirocysts I } \\
\text { Spirocysts II } \\
\text { Basitrichs }\end{array}$ & $\begin{array}{l}15.0-40.0 \times 2.0-6.0(25.5 \times 6.8 \pm 4.0 \times 1.2) \\
31.0-46.0 \times 7.0-8.0(37.1 \times 7.3 \pm 4.4 \times 0.4) \\
20.0-35.0 \times 2.0-4.0(26.7 \times 2.7 \pm 3.1 \times 0.6)\end{array}$ & $\begin{array}{r}130 \\
32 \\
125\end{array}$ \\
\hline -base & $\begin{array}{l}\text { Spirocysts I } \\
\text { Spirocysts II } \\
\text { Basitrichs }\end{array}$ & $\begin{array}{l}15.0-38.0 \times 2.5-6.5(26.7 \times 4.5 \pm 5.3 \times 0.9) \\
28.0-43.0 \times 7.0-10.0(34.9 \times 7.8 \pm 4.3 \times 0.7) \\
21.0-33.0 \times 2.0-3.0(24.8 \times 2.3 \pm 2.5 \times 0.4)\end{array}$ & $\begin{array}{r}166 \\
30 \\
59\end{array}$ \\
\hline Column & $\begin{array}{l}\text { Spirocysts I } \\
\text { Spirocysts II } \\
\text { Basitrichs }\end{array}$ & $\begin{array}{l}13.0-26.0 \times 2.0-4.0(20.7 \times 3.3 \pm 3.8 \times 0.6) \\
22.0-37.0 \times 5.0-7.0(28.4 \times 5.4 \pm 3.6 \times 0.5) \\
16.0-37.0 \times 1.5-3.0(25.3 \times 2.1 \pm 4.5 \times 0.3)\end{array}$ & $\begin{array}{r}32 \\
40 \\
163\end{array}$ \\
\hline Actinopharynx & $\begin{array}{l}\text { Spirocysts II } \\
\text { Basitrichs } \\
\text { Microbasic p-mastigophores }\end{array}$ & $\begin{array}{l}20.0-40.0 \times 5.0-8.0(29.1 \times 5.9 \pm 4.6 \times 0.7) \\
20.0-33.0 \times 2.0-4.0(26.2 \times 2.7 \pm 2.7 \times 0.5) \\
21.0-30.0 \times 4.0-6.0(24.9 \times 4.9 \pm 2.1 \times 0.7)\end{array}$ & $\begin{array}{r}209 \\
141 \\
85\end{array}$ \\
\hline Filament & $\begin{array}{l}\text { Spirocysts I } \\
\text { Spirocysts II } \\
\text { Basitrichs } \\
\text { Microbasic p-mastigophores }\end{array}$ & $\begin{array}{l}18.0-22.0 \times 3.0-4.0(20.9 \times 3.5 \pm 1.5 \times 0.5) \\
22.0-31.0 \times 4.5-8.0(27.1 \times 6.0 \pm 2.8 \times 0.9) \\
20.0-30.0 \times 2.0-3.0(25.7 \times 2.4 \pm 3.3 \times 0.5) \\
18.0-30.0 \times 4.0-6.0(24.4 \times 4.9 \pm 2.7 \times 0.6)\end{array}$ & $\begin{array}{l}10 \\
36 \\
12 \\
89\end{array}$ \\
\hline
\end{tabular}
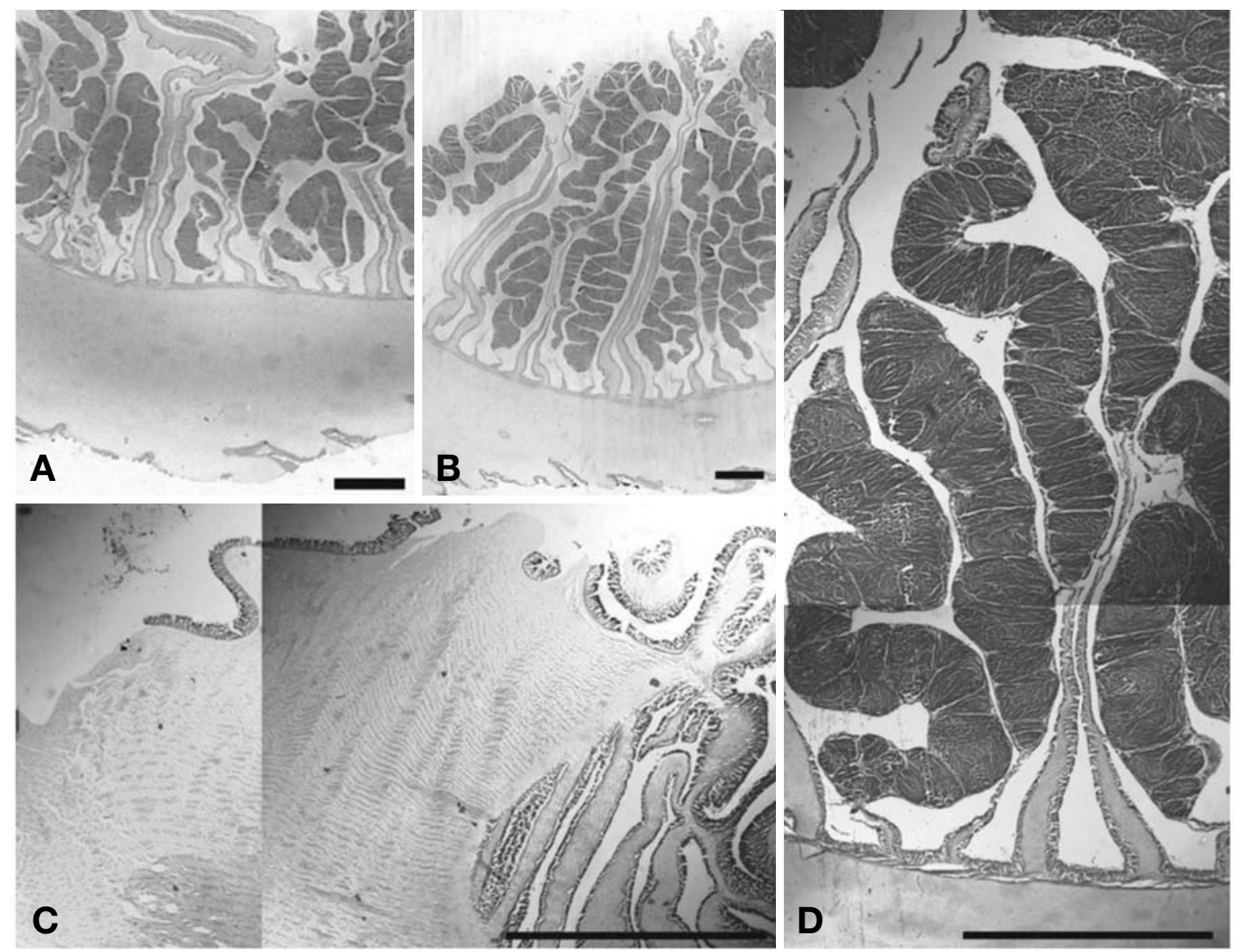

Fig. 3. Mesenteries of Calliactis polypus. A, directive, 1st, 2nd, 3rd, and 4th mesenteries; B, perfect 1st and imperfect 2nd, 3rd and 4th mesenteries; C, sphincter muscle; D, spermeries in 3rd and 4th mesenteries. Scale bars $=1 \mathrm{~mm}$.

of variable appearance, sometimes divisible into different regions; often with verrucace, marginal spherules or psedos- pherules, vesicles of other protuberances. Sphincter endodermal or mesogloeal, but sometimes absent. Tentacles and 

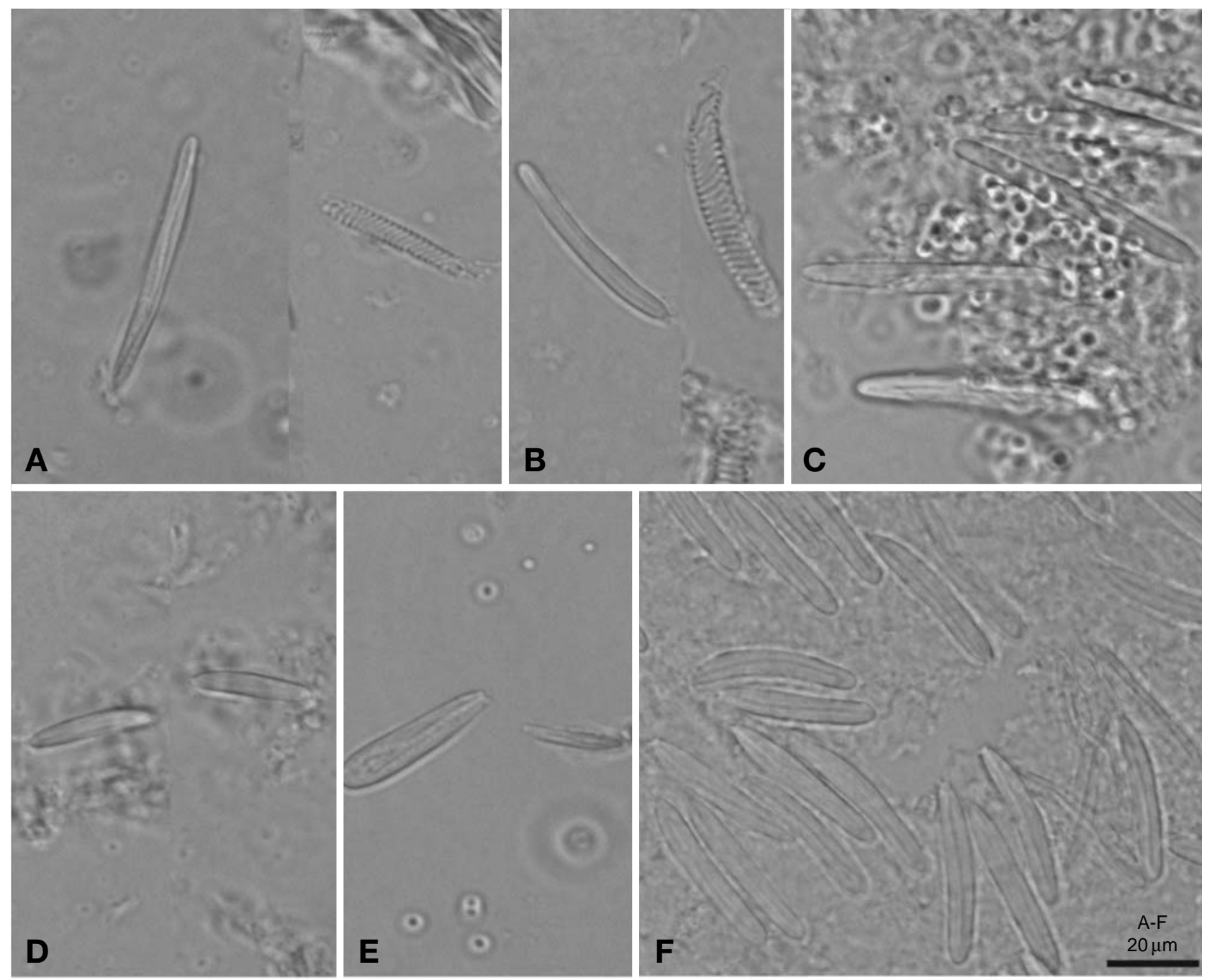

Fig. 4. Cnidae of Calliactis polypus. A, tip of tentacle; B, base of tentacle; C, actinopharynx; D, column; E, filament; F, acontia.

mesenteries numerous, former cyclically or radially arranged. Msenteries rarely differentiated into macro- and microcnemes. Retractors weak or strong, rarely circumscribed. Acontia present or absent. Three superfamilies belonged.

\section{Superfamily Acontiaria Stephenson, 1935}

Thenaria with acontia or acontia-like organ. Sphinter commonly mesogleal, sometimes endodermal or absent.

\section{Family Hormathiidae Carlgren, 1932}

Acontiaria with strong mesogloeal sphincter. Mesenteries not divisible into macro- and microcnemes. Usually 6 pairs of perfect mesenteries, sometimes more, and usually sterile, rarely fertile.

\section{Genus Calliactis Verrill, 1869}

Hormanthiidae with well developed base. Column smooth, more or less cylindrical, not or only differentiated into scapus with weak cuticle and scapulas, often thick, sometimes with numerous ectodermal invagination. No collar. Tentacles simple, conical, little short, more numerous than mesenteries at base, with longitudianal ectodermal or meso-ectodermal muscles. Cinclids present in proximal part of column from base. Sphincter strong, mesogloeal. Two broad siphonoglyphs. Mesenteris six pairs, perfect and sterile, more numerous at margin than base. Two pairs of directives. Retractors off mesenteries fairly weak, diffuse. Parietobasilar and basilar muscles weak to well developed. Commensal with hermit crabs often. 

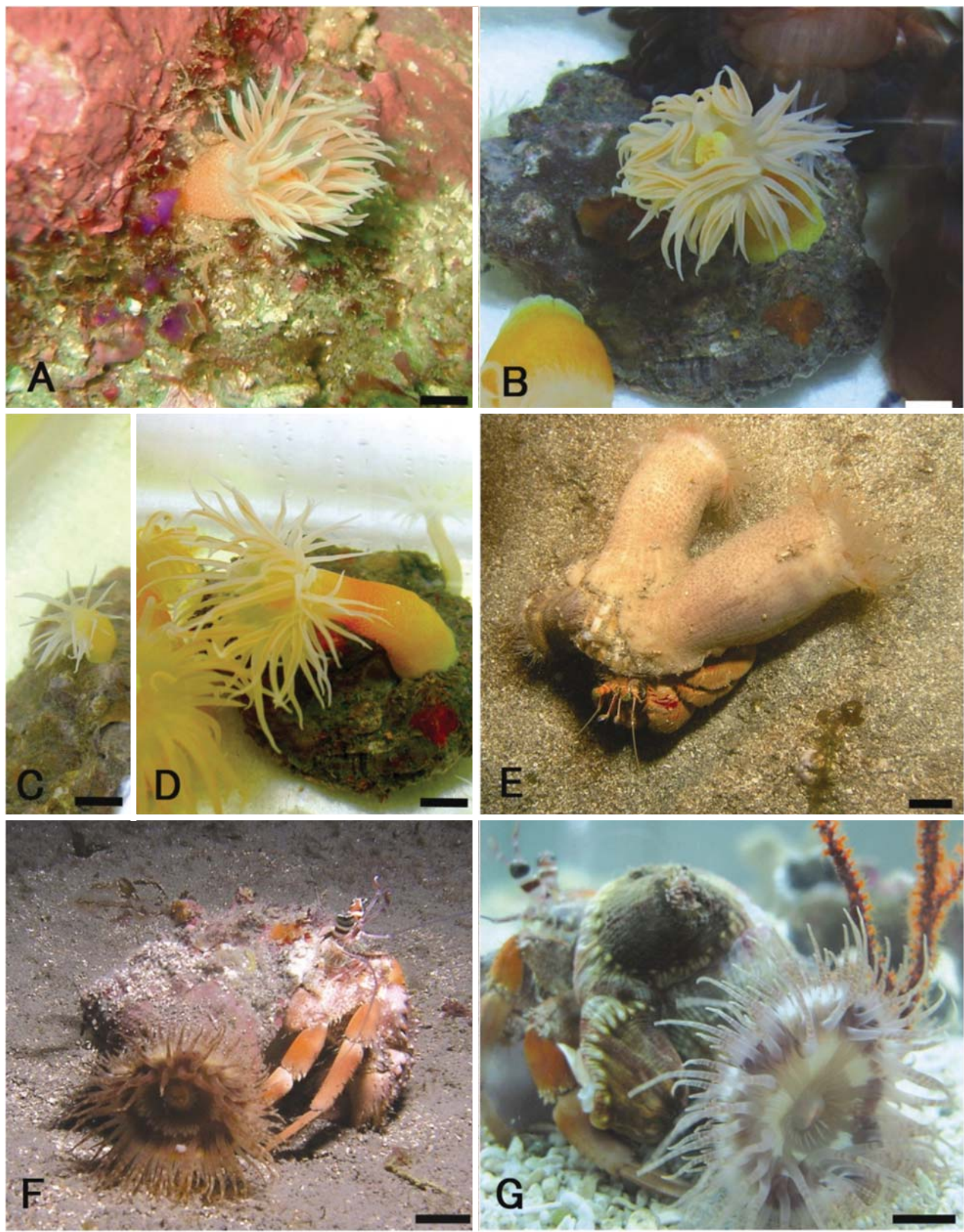

Fig. 5. Living anemones. A-D, Halcurias carlgreni; E, Calliactis japonica; F-G, Calliactis polypus. Scale bars=1 cm. 
Table 3. External size $(\mathrm{mm})$ in relation to age of Calliactis polypus ( $L$ length, $D$ diameter)

\begin{tabular}{|c|c|c|c|c|}
\hline \multirow{4}{*}{ Parts } & \multicolumn{4}{|c|}{ State } \\
\hline & \multicolumn{2}{|c|}{ Contracted } & \multicolumn{2}{|c|}{ Extended } \\
\hline & Young & Adult & Young & Adult \\
\hline & $D$ & $D$ & $D$ & $D$ \\
\hline Tentacle-inner & & $1-6$ & $12-15$ & $12-25$ \\
\hline -outer & & $0.5-1.5$ & $2-4$ & $2-6$ \\
\hline Total height & $7-14$ & $13-26$ & $15-22$ & $35-45$ \\
\hline Column & $11-18$ (diameter) & $11-36 \times 12-36$ (diameter) & 13-15 (diameter) & 28-30 (diameter) \\
\hline Oral disc & $1-13$ (diameter) & 4.5-15 (diameter) & $15-20$ (diameter) & $35-40$ (diameter) \\
\hline Pedal disc & $14-18 \times 16-26$ (diameter) & $11-38 \times 16-41$ (diameter) & $20-27 \times 33-34$ (diameter) & $45-50 \times 50-75$ (diameter) \\
\hline
\end{tabular}

Table 4. Size range and mean value of cnidae according to parts of Calliactis polypus ( $n$ number of cnidae measured)

\begin{tabular}{|c|c|c|c|}
\hline Parts & Cnidae & Length $\times$ Width $($ mean $\pm S D, \mu m)$ & $n$ \\
\hline Tentacle-tip & $\begin{array}{l}\text { Spirocysts } \\
\text { Basitrichs }\end{array}$ & $\begin{array}{l}15.0-36.0 \times 2.0-4.0(24.2 \times 2.5 \pm 4.7 \times 0.5) \\
18.0-31.0 \times 1.5-3.0(25.7 \times 2.2 \pm 2.7 \times 0.4)\end{array}$ & $\begin{array}{l}90 \\
90\end{array}$ \\
\hline -base & $\begin{array}{l}\text { Spirocysts } \\
\text { Basitrichs }\end{array}$ & $\begin{array}{l}15.0-30.0 \times 2.0-5.0(23.6 \times 3.2 \pm 3.3 \times 0.6) \\
13.0-26.0 \times 1.5-3.0(22.1 \times 2.1 \pm 1.6 \times 0.3)\end{array}$ & $\begin{array}{l}90 \\
90\end{array}$ \\
\hline Column & Basitrichs & $7.0-19.0 \times 1.5-3.0(11.7 \times 2.1 \pm 2.6 \times 0.3)$ & 90 \\
\hline Actinopharynx & Basitrichs & $14.0-30.0 \times 2.0-4.0(23.0 \times 2.6 \pm 4.0 \times 0.5)$ & 150 \\
\hline Filament & $\begin{array}{l}\text { Basitrichs } \\
\text { Microbasic p-mastigophores }\end{array}$ & $\begin{array}{r}9.0-15.0 \times 1.0-2.0(11.9 \times 1.8 \pm 1.6 \times 0.3) \\
19.0-23.0 \times 3.0-5.0(20.6 \times 4.1 \pm 1.0 \times 0.5)\end{array}$ & $\begin{array}{l}90 \\
60\end{array}$ \\
\hline Acontia & Basitrichs & $18.0-31.0 \times 2.0-4.0(22.6 \times 2.9 \pm 3.0 \times 0.4)$ & 150 \\
\hline
\end{tabular}

Table 5. Comparison of cnidae $(\mu \mathrm{m})$ of Calliactis polypus reported in the literature and this study

\begin{tabular}{|c|c|c|c|}
\hline Parts & Cnidae & See England, 1971 & This study \\
\hline Tentacle & $\begin{array}{l}\text { Spirocysts } \\
\text { Basitrichs }\end{array}$ & $\begin{array}{l}14.4-38.4 \times 1.8-4.2 \\
20.4-31.2 \times 1.8-2.4\end{array}$ & $\begin{array}{l}15.0-36.0 \times 2.0-5.0 \\
18.0-31.0 \times 1.5-3.0\end{array}$ \\
\hline Column & $\begin{array}{l}\text { Basitrichs I } \\
\text { Basitrichs II } \\
\text { Microbasic p-mastigophores }\end{array}$ & $\begin{array}{l}6.0-10.8 \times 1.8-2.4 \\
\text { Absent } \\
12.0-18.0 \times 2.4-3.0\end{array}$ & $\begin{array}{l}7.0-19.0 \times 1.5-3.0 \\
\text { Absent } \\
\text { Absent }\end{array}$ \\
\hline Actinopharynx & $\begin{array}{l}\text { Basitrichs I } \\
\text { Basitrichs II }\end{array}$ & $\begin{array}{c}12.0-15.6 \times 1.8 \text { (sometimes absent) } \\
18.0-27.6 \times 2.4-3.0\end{array}$ & $\begin{array}{c}\text { Absent } \\
14.0-30.0 \times 2.0-4.0\end{array}$ \\
\hline Filament & $\begin{array}{l}\text { Basitrichs } \\
\text { Microbasic p-mastigophores }\end{array}$ & $\begin{array}{c}9.6-15.6 \times 1.8 \\
15.6-27.6 \times 2.4-4.2\end{array}$ & $\begin{array}{r}9.0-15.0 \times 1.0-2.0 \\
19.0-23.0 \times 3.0-5.0\end{array}$ \\
\hline Acontia & $\begin{array}{l}\text { Basitrichs I } \\
\text { Basitrichs II }\end{array}$ & $\begin{array}{c}18.0-27.6 \times 2.4-3.0 \\
\text { Absent }\end{array}$ & $\begin{array}{c}18.0-31.0 \times 2.0-4.0 \\
\text { Absent }\end{array}$ \\
\hline
\end{tabular}

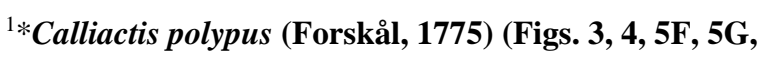
Tables 3-6)

Priapus polypus Forsskål, 1775, p. 102.

Calliactis (Priapus) polypus: Carlgren, 1900, p. 55; 1928, p. 197; 1949, p. 97.

Calliactis vincentina Pax, 1922, p. 88; Carlgren, 1949, p. 97. Calliactis valdiviae: Carlgren 1928, p. 197.

Anthothoe vincentina: Carlgren, 1949, p. 103.

Calliactis polypus: Hertwig, 1882, p. 65; Stephenson, 1920, p. 528; England, 1971, p. 23, tables 1-3, pl. 1, figs. A-C, pls. 2, 3; Uchida and Soyama, 2001, p. 31.

Materials examined. 1 ind., Jejudo Island, Seogwipo, 9 Jul. 1985 (J.I. Song); 2 inds., Jejudo Island, Seopseom (33 ${ }^{\circ} 13^{\prime}$ 51.86"N, $\left.126^{\circ} 35^{\prime} 47.67^{\prime \prime} \mathrm{E}\right), 9$ Dec. 2007 (S.J. Hwang and I.Y. Cho), 9-10 m deep; 4 inds. ד $\sigma^{\top}$, Jejudo Island, Seogwipo, 17 Apr. 2008 (S.J. Hwang, I.Y. Cho and D.S. Kim); 4 inds., Jejudo Island, Munseom ( $\left.33^{\circ} 13^{\prime} 40.82^{\prime \prime} \mathrm{N}, 126^{\circ} 34^{\prime} 05.55^{\prime \prime} \mathrm{E}\right)$,

\footnotetext{
$1 *$ 폴립집게말미잘 (신칭)
} 
Table 6. Comparison of external size $(\mathrm{mm})$ of Calliactis polypus reported in the literature and this study

\begin{tabular}{|c|c|c|c|c|c|}
\hline \multirow{2}{*}{ Parts } & \multirow{2}{*}{ State } & \multicolumn{2}{|c|}{ See England, 1971} & \multicolumn{2}{|r|}{ This study } \\
\hline & & Height & Diameter & Height & Diameter (young/adult) \\
\hline Column & $\begin{array}{l}\text { Contracted } \\
\text { Expanded }\end{array}$ & 20 & & & $\begin{array}{c}11-18 / 11-36 \times 12-36 \\
13-15 / 28-30\end{array}$ \\
\hline Oral disc & $\begin{array}{l}\text { Contracted } \\
\text { Expanded }\end{array}$ & & & & $\begin{array}{l}1-13 / 4.5-15 \\
15-20 / 35-40\end{array}$ \\
\hline Pedal disc & $\begin{array}{l}\text { Contracted } \\
\text { Expanded }\end{array}$ & & $\sim 50$ & & $\begin{array}{l}14-18 \times 16-26 / 11-38 \times 16-41 \\
20-27 \times 33-34 / 45-50 \times 50-75\end{array}$ \\
\hline
\end{tabular}

20 Jun. 2010 (S.J. Hwang, E.A. Choi and J.I. Song), 5-16 m deep.

Description. Body cylindrical but more or less flat in contracted state. Column smooth with longitudinal and horizontal striates, and has usually one circle of perforate 24 cinclides or somtimes two circles of them at limbus in lager specimens. Column wall very thin and divided into short scapulus and scapus. Oral disc circular with smooth conical tentacles at margin, and oral disc wider than column in diameter. Number of tentacles 124-190 expecting in 6 cycles of mesenterial arrangement. Pedal disc well developed, strongly adherent on gastropod shell, and in diameter, pedal disc exceeds over oral disc and column. Body size in Table 3. Inner tentacles longer than outer, and inner and outer 1-25 $\mathrm{mm}$ long and 0.5-6 mm long in adult specimens, respectively. In contracted state, height of body 7-14 mm and 13-26 mm, diameter of column $11-18 \mathrm{~mm}$ and $11-36 \times 12-36 \mathrm{~mm}$, diameter of oral disc $1-13 \mathrm{~mm}$ and $4.5-15 \mathrm{~mm}$, diameter of pedal disc $14-18 \times 16-26 \mathrm{~mm}$ and $11-38 \times 16-41 \mathrm{~mm}$ in young and adult, respectively. In extended state, height of body $15-$ $22 \mathrm{~mm}$ and $34-45 \mathrm{~mm}$, diameter of column $13-15 \mathrm{~mm}$ and $28-$ $30 \mathrm{~mm}$, diameter of oral disc $15-20 \mathrm{~mm}$ and $35-40 \mathrm{~mm}$, diameter of pedal disc $20-27 \times 33-34 \mathrm{~mm}$ and $45-50 \times 50-75 \mathrm{~mm}$ in young and adult, respectively.

Actinopharynx with two siphonoglyphs. Longitudinal muscle of tentacles ectodermal and circular muscle of column weak, diffuse. Sphincter muscle very strong, mesogloeal, and transversally stratified alveolae. Mesogloea of column very thick compared with thin ectoderm and endoderm, with thickness of about 10 to 20 times of endoderm. Mesenteries hexamerously arranged up to 4th cycles around actinopharynx. Margin and base of column have more mesentery pairs than center. First six pairs including directives, perfect and sterile, and another all mesenteries from 2 nd to 5 th cycle imperfect, usually fertile at older cycles. 1st to 4th pairs bear filaments and acontia, and also weak diffuse retractor muscles. Gonads only developed in mesenteries of 3rd and 4th cycles. Parietobasilar and basilar muscels weak. Dioceous. Spemaries observed in the specimen collected on April 2008.

Cnidom: spirocysts, basitrichs, microbasic p-mastigo- phores.

Distribution and size of cnidae are measured as follow (Table 4).

In color of living actiniarian, column dark brown mixed with yellow ocher and purple. Oral disc purplish brown, with prominent white patterns around middle of disc, and orange radiate bands around mouth. Tentacle base, one third of whole, white, and purplish brown and pale yellow circular patterns around along last two third. Yellow ocher cinclides right above limbus, and pedal disc white with longitudinally purplish brown stripes. Preserved specimens greenish.

Habitat. This species shows commensalism with hermit crab, Dardanus impressus, inhabiting on rocks or sand bed between depth of 5 and $16 \mathrm{~m}$. Four to ten individuals of this actiniarian adherent firmly to one gastropod shell bearing thick cuticle.

Remarks. It is a little different from C. polypus by Hertwig (1882) and England (1971) that the mesenteries of the 7th cycle are not developed in our specimens, but it can be occurred in the larger specimen. And also, mesogloea of column was much thicker in our specimens than in specimens by England (1971). For nematocysts of column, basitrichs are more or less longer, and microbasic p-mastigophores are absent in our specimens. However, microbasic pmastigophores were previously scarce or sometimes absent (England, 1971). This species exist together with $C$. japonica at the same habitat in Jejudo Island. However, differences between $C$. polypus and $C$. japonica are easily distinguished based on external feature such as the size and color pattern, and also type and size of cnidae (Fig. 5E-G). In C. japonica, microbasic p-mastigophores are not observed in filaments, only larger basitrichs in actinopharynx, and larger basitrichs additionally in acontia (Song and Lee, 1998). Also, column of $C$. japonica is more cylindrical and larger than $C$. polypus (Song and Lee, 1998).

Distribution. Korea (Jejudo Island), Japan (Wakayama), Pacific (French Polynesia, Great Barrier Reef, Hawaii), Atlantic (Cape Verde Islands), Indian (Maldives, Christmas Island, Aden, Red Sea, Durban, Zanzibar). 


\section{ACKNOWLEDGEMENTS}

We are grateful to a documentary director, Mr. Dongsik Kim for supplying specimens of $C$. polypus collected at Seogwipo in 2008, and also thank to Borajina Park for her devotional assistance. This research was supported by a grant from Korean Coral Resources Bank (KCRB) program funded by Ministry of Land, Transport and Maritime Affairs of Korean Government.

\section{REFERENCES}

Carlgren, O., 1900. Ostafrikanische Actinien. Gesammelt von Herrn Dr. F. Stuhlmann 1888 und 1889. Mitt. Naturh. Mus., Hamburg, 17: 21-144.

Carlgren, O., 1928. Actiniaria der Deutschen Tiefsee-Expedition. Wiss. Ergebn. D. Deutschen Tiefsee-Exped., 22: 123-266, pls. 10-13.

Carlgren, O., 1940. A contribution to the knowledge of the structure and distribution of the cnidae in the Anthozoa. Lund Univ. Arsskrift N. F. Avd., 2, 36(3): 1-62.

Carlgren, O., 1949. A survey of the Ptychodactiaria, Corallimorpharia and Actiniaria. K. Sven. Vetenskapsakad. Handl., 1(1): 91-98, ser. 4, 1(1): 1-121, 4 pls.

England, K.W., 1971. Actiniaria from Mururoa Atoll Tuamotu, Polynesia (Hormathidae; Calliactis polypus, Sagartiidae; Verrillactis n. gen. paguri). Cah. Pac., 15: 23-39, pl. 4.

Fautin, D.G., 2009. Hexacorallians of the World. http://geoportal. kgs.ku.edu/hexacoral/ anemone2/index.cfm.

Forsskål, P., 1775. Descriptiones animalium Avium, Amphibiorum, Piscium, Insectorum, Vermium; quae in itinere orientali observait. Mölleri, Havniæ, pp. 1-164 (cited from
Carlgren, 1949).

Hertwig, R., 1882. Report on the Actiniaria dredged by H.M.S Challenger during the years 1873-1876. Report Scient. Results Challenger Zool., 6: 1-136, pl. 14.

Manuel, R.L., 1988. British Anthozoa. Linn. Soc. Lond. \& Estuarine and Brackish-water Sciences Association, Avon, Great Britain, 18: 1-232.

McMurrich, J.P., 1901. Contributions on the morphology of the Actinozoa. VI. Halcurias pilatus and Endocoelactis. Biol. Bull., 2: 155-163.

Pax, F., 1922. Diagnosen neuer Actininiarien aus der Ausbente der Deutschen (1901-1903) und der Französischen (19081910) Südpolar-Expedition. Zool. Anz., 54(3/4): 74-92.

Song, J.I., 2004. Illustrated encyclopedia of fauna and flora of Korea. Vol. 39 Anthozoa. Ministry of Education \& Human Resources, Seoul, Korea, pp. 1-643.

Song, J.I. and H.R. Cha, 2004. Three new records of Actiniaria (Anthozoa: Zoantharia) from Korea. Korean J. Syst. Zool., 20(2): 201-214.

Song, J.I. and I.S. Lee, 1998. Fauna of anthozoans from adjacent waters of Geojedo Island in Korea. Korean J. Syst. Zool., 14(3): 229-242.

Stephenson, T.A., 1920. On the classification of Actiniaria part I. Forms with acontia and forms with a mesogloeal sphincter. Q. J. Microsc. Sci., London, 64: 425-574, pl. 22.

Uchida, H., 2004. Actinologia japonica (1) on the actiniarian family Halcuriidae from Japan. Kuroshio Bioshere, Japan, 1: 7-26, pl. 1.

Uchida, H. and I. Soyama, 2001. Sea anemones in Japanese waters. TBS Britanica, Tokyo, Japan, pp. 1-158.

Received September 29, 2010 Accepted November 12, 2010 